\title{
Vulnerable City, recipient city, or climate destination? Towards a typology of domestic climate migration impacts in US cities
}

\author{
Anna Marandi ${ }^{1} \cdot$ Kelly Leilani Main ${ }^{2}$ \\ Accepted: 22 April 2021 / Published online: 4 August 2021 \\ (c) AESS 2021
}

\begin{abstract}
Globally, the impacts of climate change will uproot and displace millions of individuals, and American cities are on the frontline of these future population shifts. Our analysis of empirical documentation of migration factors as well as theoretical demographic models shows three predominate types of US cities affected by climate migration pathways: (1) vulnerable cities-those that will suffer significant losses in population and tax revenue; (2) recipient cities-those that serve as unsuspecting or unwilling "receiving communities" from sudden-onset disasters without preparation; and (3) climate destinations - cities seeking to rebrand their communities as "climate havens" that welcome displaced residents through equitable planning and preparation. Despite the evidence of such migration trends, there currently is limited guidance for governments at any scale to plan and prepare for these changes. Forced or unplanned migrations will have a profound and disproportionate impact on communities of color, the elderly, and other at-risk populations that are already experiencing the compounding effects of climate and environmental injustices. A lack of adequate preparation and resources dedicated to minimizing the impacts of planned and unplanned migration pathways could exacerbate existing economic, environmental, and social inequalities. Drawing from case studies in cities across the country that illustrate the typology outlined above, this paper presents a framework with preliminary strategies for policy makers to bridge knowledge gaps and design responses for both short- and long-term planning initiatives. In particular, we encourage the use of typological frameworks for implementing scenario planning that can help cities navigate the challenges of planning for future climate-migration to plan for more sustainable, inclusive, and equitable cities for all.
\end{abstract}

Keywords Climate migration $\cdot$ Managed retreat $\cdot$ Equity $\cdot$ Justice $\cdot$ Climate change

\section{Introduction: climate change impacts on US communities}

As the US emerges from one of the hottest, most disasterfilled summers to date, the message is clear: grossly unprepared, we are entering an age of forced adaptation, and migrating out of harm's way is not only a viable, but an essential adaptation strategy. In 2018, more than 16 million people were displaced by weather-related disasters globally, 1.2 million of whom lived in the USA (Martín, 2019). Disasters are also costly: 2019 was the fifth consecutive year (2015-2019) in which 10 or more billion-dollar weather

Kelly Leilani Main

klmain@mit.edu

National League of Cities, Washington, DC, USA

2 Massachusetts Institute of Technology, Boston, MA, USA and climate disaster events have impacted the USA (NOAA, 2020). The climate crisis will continue to push these numbers even higher, with increased storm surge, high tide flooding, and saltwater intrusion in coastal areas; more wildfires in the West; increased precipitation and flash floods in the Northeast; and heatwaves and drought in the Great Plains and western states (USGCRP, 2018).

Despite these dire forecasts, Americans continue to move to high-risk areas in ever greater numbers. People are flocking to the South, seeking affordable housing, job opportunities, and warm weather in Sun Belt cities like Atlanta, Las Vegas, and Austin (Fulton et. al, 2020). More Americans die from heat exposure than any other weather-related event, and due to these migration trends, four to six times more people in the USA could be exposed to extreme heat by the latter half of the twenty-first century (Jones et al. 2015). More Americans have also been moving into the wildland urban-interface (WUI), where wildfire risks are 
most pronounced Mann et al., 2014). From 1990 to 2010, there was a $41 \%$ increase in the number of new homes in the WUI, making it the fastest growing land use type in the country (Radeloff et al., 2018). Additionally, $40 \%$ of the population of the USA lives in coastal areas, with over half a million square kilometers in the Low Elevation Coastal Zone (LECZ), threatening as many as 43 million people by 2100 (Hauer et al. 2020; Neumann et al., 2015). Land loss, saltwater intrusion, erosion, and vulnerability to storm surge could render today's coastal communities uninhabitable before complete inundation (Hauer et al. 2020). Despite the increase in publicly available flood risk data, eastern coastal states such as Connecticut, Delaware, New Jersey, Rhode Island, New Jersey, Florida, and North Carolina are all developing new housing in vulnerable zones two to three times faster than in safer locations (Climate Central \& Zillow, 2019).

The shortsightedness of current housing market trends and preferences threatens millions of residents across the country and postpones the inevitability of relocation away from high-risk areas (USGCRP, 2018; GAO, 2020). All scales of governments are woefully unprepared to manage complex and costly relocation processes (Herrmann, 2017). In the absence of clear federal leadership, support for addressing the threat of climate change on American cities and their residents has been provided only on an ad hoc basis by local governments who are already facing budget shortfalls (GAO, 2020). Increasingly, managed retreat, "a deliberate and strategic "move from climate induced harm" (Ajibade et al., 2020), is seen as a necessary, viable, and even desirable adaptation strategy (Hino et al., 2017; Siders, 2019; Spidalieri \& Bennett, 2020; Plastrik \& Cleveland 2019) despite the social and political challenges (Freudenberg et al., 2016; Koslov, 2016). For example, a recent report from the US Government Accountability Office (GAO) recommends that Congress establish "a pilot program with clear federal leadership to identify and provide assistance to communities that express affirmative interest in relocation as a resilience strategy" (GAO, 2020). High-profile cases in Staten Island (Brady, 2015), Isle de Jean Charles (Nijhuis, 2017), and Indigenous Alaskan communities (Climigration, 2019) highlight successes and failures of managed retreat programs, although a replicable model does not currently exist. In contrast to managed retreat, Plastrik and Cleveland (2019) outline two highly undesirable alternatives to the planned retreat strategy: disaster driven retreat and market driven retreat - both of which produce outcomes that are disproportionately burdensome to lower income neighborhoods and residents. The former is characterized by a loss of population after a climate disaster - an "indicator of retreat under duress" (Plastrik \& Cleveland, 2019). Market-driven retreat, on the other hand, is stirred by the fear and anticipation of negative financial impacts due to climate change on the part of a town's property owners, developers, investors, financial lenders, and insurers. This then triggers a "cascade of disinvestment in local development, resulting in abandonment of property, decline of neighborhoods, and other distress" (Plastrik \& Cleveland, 2019). These scenarios pose a major threat to the stability of local governments (Betsill \& Bulkeley, 2006) and the well-being of communities across the country-particularly the under resourced and historically marginalized (Shi et al., 2016).

While the debate on retreat scenarios continues, this paper focuses on a broader umbrella of climate adaptation pathways: climate migration. Rather than highlight the institutions, policies, and procedures which enable relocation, such as managed retreat, climate migration encompasses a much broader range of human mobility elements (Ajibade et al., 2020). We use climate migration broadly with the goal of simplifying the climate migration landscape for US policy makers at all scales, and to highlight the inequitable outcomes that can occur when local governments are unprepared for resident movement in response to environmental triggers. In this paper, we first provide a review of existing climate migration literature to add context and highlight conversations among scholars, practitioners, and policy makers in the USA. Then through a review of case studies, we provide a basic strategy for identifying the various types of climate migration impacts on US municipalities: vulnerable cities (type 1), recipient cities (type 2), and climate destinations (type 3). This typology is designed to provide local governments with a guiding and non-binding framework to identify how they may be impacted by climate migration and the potential policy pathways to produce more equitable outcomes at the local level.

\section{(Climate) migration}

Both voluntary and forced migrations, including those that occurred due to environmental changes, are at the very foundation of the USA. There is a painful legacy of exploitation, injustice, and inequity in the forced relocation and dispossession of Native Americans, the Great Migration of six million Southern Blacks to northern cities (Wilkerson, 2011), the Dust Bowl migration of the 1930s (America's Great Migrations Project, n.d.), and the "repatriation" of nearly 500,000 Mexican Americans to California (Mckay, 1982). Americans remain on the move: to this day, roughly $10 \%$ of the population, or forty million people, move every year (Census, 2019). These in- and out-migrations have long-term ramifications on the people who move, the communities that receive them, and the cities and towns they leave behind. White flight, redlining, and gentrification are just a few of these resounding legacies and are already cause for deep concern, potentially magnified and exacerbated 
by the climate crisis, which will undoubtedly spur one of modern history's greatest migrations (Rigaud et al., 2018; McLeman \& Hunter, 2010). A growing body of evidence indicates that past and current publicly funded initiatives to facilitate migration through planned programs (such as managed retreat) may exacerbate existing inequities among communities of color and the under-resourced due to a lack of transparency, political motivations, and cost-benefit logics that promote disproportionate retreat in low-income neighborhoods (Siders, 2019). Understanding the impetus and motivations for relocation, whether top-down or individually motivated, is critical to understanding the implications of migration on issues of justice and accountability.

Not all climate migration happens for the same reason. Under duress, evacuees tend to make shorter, in-state or even in-county moves - usually where there are existing networks or family (Eyer et. al, 2018). But migration can also be motivated by several factors including but not limited to labor markets, amenities, housing, and social networks and kinship ties (Hauer, 2017; Clark \& Maas, 2013). These various factors can be broadly broken down into "push" factors and "pull" factors, where push factors are factors that drive a person from a place; pull factors are those that draw someone to a place. And although coverage on climate migration specifically may be relatively new, environmental changes have always been a part of the push/pull equation. Environmentally influenced migration may be broken down as a response to environmental calamities (shocks); environmental hardships (stressors or their obverse benefits); environmental amenities (like milder weather); and environmental barriers and their management (i.e., heating, air conditioning, flood control, and irrigation) (Gutmann \& Field, 2010). For example, studies indicate that college graduates are willing to pay more to live in milder climates (pull factor) while extreme heat in southern and western states could result in residents moving to other regions of the country (push factor) (Sinha \& Cropper, 2013; Cragg \& Kahn, 1997; Albouy et al., 2016; Fan et al., 2016).

Warner et al. (2010) posits three options for people faced with environmental degradation: first, they can stay and adapt to mitigate the effects of environmental change; second, they could do nothing and face a lower quality of life, or lastly, they can leave the affected area. It is important to note that government policy plays a huge role in influencing the push and pull migration factors by creating regulations and restrictions that dictate how, when, and where people can move (Warner et al 2010). Within these broad categories, not all push and pull factors are created equal. For example, sudden-onset events take place unexpectedly, over short periods of time, and include tornadoes, hurricanes, floods, wildfires, extreme wind, extreme precipitation, and snow events (McLeman \& Hunter, 2010). These hazards have the potential to cause considerable infrastructural damage and loss of life and are often associated with unforeseen migration or temporary displacement (McLeman \& Hunter, 2010), such as evacuations. Ferris (2014) notes that heat waves may also considered to be sudden onset, though they are far less likely to destroy property or cause displacement. In contrast, slow-onset climate changes such as droughts, land degradation, or oscillations in precipitation patterns do not typically incite permanent relocation in short time frames (McLeman \& Hunter, 2010). Some have proposed further categorization of climate migrants, such as (1) recipients of buyouts after disasters; (2) "households who independently move because of personal risks to health, property, and wellbeing"; and (3) evacuees who eventually settle in the places they move to after a disaster event. The data on where these climate migrants go is uncertain because it is very difficult to track (Martín, 2019). While it may be difficult to categorize climate migrants definitively, it is clear that people will continue to move in response to the environmental, social, and economic impacts of climate change, and that not all migration will happen through coordinated management efforts like managed retreat. Due to the tenuous understanding we currently have of exactly how climate migration will occur and when, some demographers have attempted to model migration to help cities and regions better understand their potential migration futures.

\section{The utility of demographic models}

Theories about climate migration can be translated into projected numbers by scholars using climate modeling scenarios to estimate future population flows. This field is relatively understudied and, in fact, many demographers are reluctant to generate climate-related population projections due to the uncertainty of climate models and limited data about household perceptions of climate risk thresholds (Hayes, 2016). However, the demand for relevant data by governments at all scales, utilities, and the private sector is increasing, and so a few scholars are finding creative ways to respond using agent-based modeling (ABM) (Beckwith, 2019) demographic trends and simulations (Hauer, 2017), artificial intelligence (Robinson et. al, 2020), and models comprising economic, environmental, and decision-making data sets to determine cross-border climate migration (Lustgarten, 2020). While the question of when and exactly who remains unknown, and methodologies vary, it is well understood among demographers and geographers that individuals move via pre-existing pathways and use established social and familial networks when determining where they chose to relocate (Hauer, 2017; Gutmann \& Field, 2010; Findlay, 2011).

While pre-existing pathways can help inform where people will move to, the climate models also show where 
people are likely to move from, due to exposure to environmental hazards. Climate migration projections based on sea level rise alone by Hauer, (2017) suggest that "Austin TX, Orlando FL, Atlanta GA, and Houston TX could see more than 250,000 previously unforeseen future sea level rise net migrants each," while "thirteen U.S. Core Based Statistical Areas (CBSAs) could see more than 100,000 sea level rise net migrants by 2100 with $1.8 \mathrm{~m}$ of sea level rise" (Hauer, 2017). His projections also include population losses due to sea level rise of over 100,000 residents in ten CBSAs. Notably, Miami FL is projected to lose over 2.5 million residents (Hauer, 2017).

Although the field of climate migration modeling is still in its infancy, these projections provide practitioners with valuable glimpses of future scenarios under a variety of conditions. Undoubtedly, these projects depend on societal and governance choices around climate mitigation and adaptation today, as well as the numerous, wide-ranging political, economic, and societal factors that can encourage or obstruct migration (Hauer et al., 2020) - all of which remain to be seen. While it remains an imperfect science, demographic climate migration models can be used in conjunction with the following proposed typology to help communities understand how they will be affected by climate impacts and subsequent migrations. In particular, we hope that the following case studies bring more context to different migration scenarios and illuminate the importance of local planning and decision-making in the face of demographic changes.

\section{Our contribution: establishing a climate migration typology for US cities}

After careful analysis of the growing literature surrounding climate migration from academics and researchers, empirical examples of climate migration occurring between US cities from news coverage surrounding disaster events, and a review of existing demographic models highlighting potential migration pathways, we propose that most US cities are likely to fall within three broad categories of climate migration: those cities that will suffer losses in population and tax revenue, whether temporarily or permanently (vulnerable cities); those cities that serve as unsuspecting, unwilling, or unprepared recipients following sudden-onset disasters (recipient cities), and cities seeking to rebrand their communities as climate havens, ready to welcome climate migrants through equitable planning and preparation (climate destinations). Due to the limitations in peer-reviewed literature on empirical examples of climate migration case studies, our investigation of typological case studies uses data gathered from news outlets and journalists to illuminate how existing stressors such as income and racial inequality can be compounded by climate migration caused by sudden-onset and slow-onset environmental disasters. The existing challenges faced by many governments due to budget shortfalls, the outfalls of the COVID-19 pandemic, or a lack of affordable housing can quickly spiral into a crisis for local governments who may be unaware of climate migration possibilities within their own community. The following three sections highlight case studies within the three city types outlined above with the goal of defining each type and illuminating some of the drivers and outcomes of such potential climate migration futures. In doing so, we hope to take climate migration possibilities out of theoretical assumptions and reveal concrete impacts that local decision makers can understand and prepare for.

\section{Type I: Vulnerable Cities}

While some cities have yet to feel the impacts of climate change, other cities are already experiencing chronic flooding at high tide, hurricanes, droughts, and wildfires. These sudden-onset and slow-onset disasters are shifting perspectives on where people feel safe and want to live. Well-known cases of communities at risk or who have already experienced population loss include Staten Island after Hurricane Sandy (Lavey, 2014); Newtok and Shishmaref, Alaska, where Indigenous communities are threatened by coastal erosion and permafrost thaw (Bronen, 2013); the Chesapeake Bay (Arenstam Gibbons and Nicholls, 2006); and Isle de Jean Charles, Louisiana, which is facing significant sea level rise impacts (Davenport \& Robertson 2016). While local impacts are acute, some climate-vulnerable areas are already starting to show depressed property values at broader scales (Keenan et al., 2018). A 2019 study by First Street Foundation found that coastal real estate from Main to Mississippi lost nearly $\$ 16$ billion in value from the period 2005 to 2017 (First Street Foundation, 2019). A 2018 report from the Union of Concerned Scientists estimated that 300,000 properties totaling roughly $\$ 136$ billion will be at risk of chronic flooding by 2045 and that by $2100,2.5$ million properties, worth over a trillion dollars today, will be at similar risk (Dahl et al., 2018). Beyond immediate and long term financial setbacks including the costs of rebuilding and temporary housing (Ratcliffe et al., 2019), recurrent disasters have negative mental health consequences on populations due to the erosion of certain psycho-social contexts (Wind et. al, 2013) and the potential loss of intangibles such as cultural heritage (Wiggins, 2018). After time, this psychological toll on residents may reduce the likelihood of people returning after repeated exposure as perception of risk increases. It is important to note that the time scales under which people leave a city, and whether or not they return, is highly uncertain. Many of the most climate-vulnerable metropolitan areas such as Miami-Fort Lauderdale, West Palm Beach, FL, Houston, and the Woodlands in Sugar 
Land, TX (Collins et al., 2018) also rank among the top ten most populous regions and continue to experience significant population growth (US Census Bureau, 2019). The following case studies illuminate vulnerabilities across two separate time scales: sudden-onset population loss following a disaster event and slow-onset threats from chronic flooding and limited municipal budgets. In both cases, such vulnerable cities' most vulnerable residents are the most at risk from displacement and other climate threats.

\section{Sudden-onset population loss: New Orleans, Louisiana}

Hurricane Katrina, which killed approximately 971 Louisianans (Brunkard et al., 2008) and caused more than $\$ 100$ billion in property damage to the Louisiana coast in August 2005 (Deryugina et al., 2018), changed the American conception of environmental calamity. Hurricane Andrew of 1992 had been by far the costliest natural disaster before then, leading to the evacuation of 350,000 residents of Dade County (now Miami-Dade County), Florida, 40,000 of whom were permanently displaced (Smith \& McCarty, 1996). By comparison, the entire population of New Orleans, nearly half a million people, were temporarily displaced by Hurricane Katrina, and about half of this population still had not returned home 1 year after the hurricane (Hori et al., 2009). In 2009, the population of Louisiana's capital was still 23\% lower than before Hurricane Katrina made landfall 4 years earlier (Gutmann \& Field, 2010, citing Greater New Orleans Community Data Center, 2009). While Hurricane Katrina was not the first displacement crisis and surely will not be the last, it has become stark symbol of the inequities of a city's most vulnerable residents in the recovery process. Although New Orleans' economy has recovered over the last 15 years, it has come at the expense of the displacement and continued disenfranchisement of the city's African American population (Zaninetti \& Colten, 2012) and gentrification of historically black neighborhoods (Aune et al., 2020). One study of gentrification in post-Katrina New Orleans found that neighborhoods with a "higher percentage of physical building damage were more likely to have gentrified one decade after the storm" (van Holm \& Wyczalkowski, 2019). More disturbingly, the results of the study highlight that although displacement is less likely to occur in neighborhoods with a higher African American population, displacement also enabled gentrification precisely because so many African American residents left the city (Florida, 2019, citing van Holm \& Wyczalkowski, 2019). This process illuminates that rather than create new vulnerabilities, sudden-onset disasters are likely to exacerbate existing displacement patterns that may make it too expensive for lowincome residents to return after being evacuated (Gutmann $\&$ Field, 2010).

\section{Slow-onset change: sea level rise in Tyrell County, North Carolina}

On the other hand, slow-onset changes such as sea level rise are likely to create less obvious impacts as the costs of flooding and maintenance may increase slowly in an inverse to property values over time. As illustrated through the demographic models above, more than 25 counties would see 100,000 residents impacted under a 1.8 m SLR scenario (Hauer et al., 2016). Three low-lying counties would face catastrophic impacts: Tyrrell, North Carolina; Monroe, Florida; and Hyde, North Carolina would see $94 \%, 88 \%$, and $82 \%$, respectively, of their populations at risk of inundation without sufficient adaptation measures (Hauer et al., 2016). Tyrell County has a very small population (just over 4,000), $30 \%$ of whom live below the poverty line, and $40 \%$ of whom are African American (US Census Bureau, 2019). In addition to its environmental woes, the county is facing a crippling economic hit from the COVID-19 pandemic and faces chronic septic and sewer issues due to sea level rise (Kozak, 2020). The county is expecting a 35\% drop in its sales tax revenue, and the state prison, previously the largest customer of the water and sewer utility program, just closed its door (Havlak, 2020). For many smaller and critically underfunded local governments, climate change adaptation is simply not a topic that elected officials or residents consider or discuss. As sea levels rise and communities are faced with chronic nuisance flooding, budgets become strained and the tradeoffs between basic municipal services and adaptation measures become increasingly difficult to disentangle. As described by County Manager David Clegg in the Carolina Journal, "It's not an issue of what to cut, it's what service don't you want to provide" (Havlak, 2020). Primarily low income or very low income, the residents of such communities face significant negative impacts and may be permanently displaced or dispossessed as they seek dryer ground. Without additional state or federal government assistance, some residents without the financial means to relocate may also be forced to remain in place and face an increasingly dire quality of life as services are cut.

The case studies above illustrate that some cities are likely to lose population due to climate change. The consequences of population loss on a community can be stark: fewer residents and lower property values means less property tax revenue, less revenue for local or regional utilities (DeGood, 2020), and ultimately fewer social resources and fewer opportunities for investments in critical infrastructure. This positive feedback loop means cities have fewer resources to implement adaptation or resilience initiatives, leading to further vulnerabilities of populations living in environmentally hazardous areas. If the situation described above sounds familiar, it should-the patchwork fallout of buyout programs or abandoned post-disaster neighborhoods 
show striking similarities to the tradeoffs and challenges faced by the industrial rust belt cities of North America and Europe. Following massive economic and demographic shifts, once booming cities became nearly empty, filled with delinquent and foreclosed properties, declining tax revenues and increasing infrastructure costs burdens. Fortunately, environmental hazards do not necessarily need to result in population loss. With careful planning, cities can implement smart adaptation strategies that reduce the financial burden of hazard exposure. For example, Norfolk, VA, has become widely known for its Vision 2100, a proactive zoning approach to slowly incentivize managed retreat from low-lying areas by up zoning in the city's uphill economic corridors (City of Norfolk, 2016). Nearby Chesapeake, VA, has also taken an innovative partnership model with two non-profit organizations, Wetlands Watch and the Living River Trust, to transfer previously bought-out properties to a conservation organization for management and upkeep (Dietrich, 2020). Warren, RI, is developing a strategy for adapting to chronic flood risk through relocation: the town's recent "Market to Metacom: Adaptation and Improvement" plan provides a blueprint for relocating commercial activity away from the lowest-lying areas to a new economic corridor on higher ground (Sherman, 2020). Said Bob Rulli, the town's director of planning and community development, "The buyout piece will take time, but I would rather start now and plan now than wait for a disaster to happen" (Sherman, 2020). These types of innovative initiatives will be critical for building a robust field of adaptation moving forward, but they still risk exacerbating inequalities between towns that have the resources to plan, and those that do not. Without specific resources dedicated to helping low-income communities relocate, there may be few options for residents to stay within their communities.

\section{Type 2 cities: Recipient Cities}

Thus far, of cities either directly or indirectly impacted by sudden-onset events, communities on the receiving end of the climate migration equation are the least understood or supported. Although studies of larger cities such as Houston after Hurricane Katrina and buyouts from Staten Island are relatively well documented (see, for example Binder \& Greer, 2016), there is little awareness around the social, economic, and political implications on small- and mid-sized cities who are faced with significant demographic changes, often overnight. Due to the increasing number and size of sudden-onset events and their subsequent evacuations, we are beginning to identify commonalities across cities of all sizes that play host to retreating residents and eventually, long-term resettlements. We call this second type the recipient city. Recipient cities are often the nearest center to rural areas or other regional cities who face specific climate risks, but they are marginally less vulnerable to certain impacts than their neighboring communities. However, unlike large cities which have resources to assimilate more relocatees, Recipient Cities are often smaller and mid-sized cities with their own share of social, economic, or environmental stressors. As a result, they are disproportionately impacted when large numbers of newcomers suddenly arrive, due to the subsequent strain on public, medical, and social services. These gaps in turn affect the city's frontline communities-the elderly, communities of color, less-resourced or less socially connected residents, and non-English speaking communities. To illuminate this city type, we explore media coverage of two cities that were recently overwhelmed by an influx of climate migrants responding to sudden-onset disasters.

\section{Chico, California}

In November 2018, the Camp Fire destroyed 14,000 homes in Paradise, California. The majority of evacuees fled 14 miles west to the city of Chico-the nearest urban center and regional economic hub-and within a few days, nearly 20,000 evacuees and hundreds of emergency responders were staying at emergency shelters, hotels, rentals, or camped out in the Walmart and Target parking lots (Hagerty, 2019; Romero, 2018). Almost overnight, the college town saw growth not expected for an additional two decades (Rainey, 2019). As City Manager Mark Orme described, "Really in one word, it's overwhelming. Obviously when you have a city in excess of 93,000 individuals and suddenly you have a 15-20 percent shift in population, it's huge.... Chico was not ready for this" (Wade, 2019). Chico's city services were stretched thin with additional traffic, degraded streets (Rainey, 2019), an uptick in car accidents, robberies, and assaults (Wilson, 2019), and a 16\% increase in average daily sewage flows (Wick, 2019). High school students were accommodated in an old Facebook satellite campus (Washburn, 2018). Mental health needs were high, with many residents suffering from post-traumatic stress disorder, depression, and illness (O’Neill, 2019; Wulfhorst, 2019; Meyers, 2019). Chico's housing vacancy rate was less than 1 percent before the disaster (Butte Countywide Homeless Continuum of Care, 2017). After the fire, the housing shortage became a full-blown crisis with rapidly rising rents and evictions (Wilson, 2019). By winter, home sales had doubled, and prices jumped 21\%: Realtor.com even designated Chico the "hottest market in the country." Although local businesses benefited from the overnight growth, others struggled to keep up with hiring needs due to rising rents (Rainey, 2019). Chico officials sought half a billion dollars to address the city's challenges, which was excluded from federal disaster funds due to its location outside of the designated burn area. Instead, the city was given a paltry $\$ 3$ million from the California legislature (Snarr, 2019). Socially and politically, 
the initial compassion of Chico's residents devolved into resentment as rents rose and evictions increased, forcing local officials to act (Siegler, 2019b; Klein, 2019; Wilson, 2019). In Paradise, water contamination and the ongoing recovery challenges caused significant delays in reconstruction (Siegler, 2019a).

For many residents of Paradise, the situation turned into a permanent displacement crisis, with evacuees either unwilling or financially unable to return and rebuild (Sellers, 2019a, b; Palinkas, 2020). Such protracted displacement may speak to the futility of differentiating between evacuees and migrants when it comes to housing and highlights the inequities of reconstruction, where those with means can rebuild and those without cannot, leading to gentrification in a town still reeling from catastrophe. City officials plan to rebuild Paradise as a fire-resistant model for other towns in the WUI, but the added costs of home building amidst a housing crisis in the state are excluding lower income individuals from participating in this reconstruction (Sellers, 2019a, b). Wealthy newcomers have purchased massive lots with treeless views from lower-income homeowners who sold their empty lots for a few thousand dollars.

While the situation in Paradise represents the most inequitable outcomes of disaster, Chico has risen as a model of resilient action in the face of dire straits. In the first year after the fire, Chico unveiled its own Green New Deal policy to protect its residents and its neighbors from reliving the horrific break down of social safety nets highlighted by the Camp Fire. The inability to effectively provide care for self and other during a moment of crisis revealed how "the impacts of climate disruption simply cannot be handled without big structural changes [because].... sustaining that empathetic impulse beyond the initial emergency takes more than good will. It takes good policy, alongside serious public investments" (Klein 2019). Chico's Green New Deal program aims to create green jobs and reduce car traffic while prioritizing sustainable public transit options. It also narrows in on affordable housing to mitigate against the harm of increasingly probable future displacement crises. As fire seasons in the American West grow ever longer and hotter, it remains to be seen whether this type of holistic policy shift can create a replicable model for other Recipient Cities.

\section{Orlando, Florida}

In 2017, Hurricane Maria caused nearly $\$ 90$ billion dollars in damage to Puerto Rico and killed over 3,000 people. Nearly a quarter of a million Puerto Ricans fled to Florida, New York, New Jersey, Pennsylvania, Connecticut, Illinois, and Massachusetts (Hinojosa et al., 2018): the vast majority of whom went to Orange and Osceola Counties in Central Florida (Echenique, 2018). Although official totals do not exist, estimates put the total number of Puerto Ricans who arrived in Orlando at around 25,000, including nearly 1,800 new students enrolled in K-12 schools (Ruiter, 2017). Organizations like the Hispanic Office for Local Assistance, or HOLA, were critical for helping new arrivals to the city find jobs, housing, and health care. Although the established tourism industry provided a massive amount of short-term housing (Sesin, 2017), long-term affordable housing became a major issue, with many people given temporary housing in motels that were isolated in areas with poor infrastructure and no public transportation (Alvarez, 2017). Despite quick response times, these preliminary efforts did not turn into long-term positive outcomes for climate migrants who arrived in Orlando. A survey conducted between February and April 2018 of Puerto Ricans who resettled in Central Florida after Hurricane Maria found that despite strong cultural ties, participants in Central Florida reported having a harder time finding jobs, housing, and transportation than their counterparts in Southeastern Florida, especially those who did not speak English (Padro Ocasio, 2019). A separate analysis by Peri et al. (2020) determined that overall employment in the city increased by $0.4 \%$ and by $4 \%$ in the construction sector and that new workers were fully absorbed into the local economy. While Orlando may have been unprepared for the original influx, they have learned a great deal in a short period of time. As Chris Castro, a senior adviser to Orlando Mayor Buddy Dyer, said "[in 2017'] we were caught off guard.... No local government, to my knowledge, is prepared ... to deal with the flux of environmental migrants and climate refugees. ... It's now very much part of our thought process" (Gramling, 2020). In fact, the city has begun to see itself as a destination for future climate migrants who may leave the island in the event of another major disaster, or just for economic opportunity. Puerto Rico's population is projected to decrease from $3.33 \mathrm{M}$ people in 2017 to $1.65 \mathrm{M}$ people in 2047 , representing a nearly $50 \%$ decrease in population over the next 30 years (Keenan \& Hauer, 2020). As a result of its welcoming efforts and existing social networks, Orlando will likely remain a short or even longer-term destination for Puerto Rican households as well as for migrants leaving coastal towns and cities in Florida.

As shown in the case of Orlando, it is critical for cities to establish partnerships with aid organizations, the private sector, and community-based organizations (CBOs) to fund and provide a coordinated response so that incoming residents can stay and thrive in their new communities. A sudden influx of newcomers can exacerbate existing stressors such as income inequality, housing shortages, or inadequate transportation plans. Despite their awareness of these risks, many type 2 cities may be sorely unprepared to respond, especially as the economic fallout of COVID-19 threatens to push their economies to their financial brink (McFarland \& Pagano, 2020). After an initial period of instability, the 
recipient cities we examined have been able to regroup and refocus their efforts on building community resilience across issue areas and incorporating social equity into these future plans. Due to the unpredictable nature of disasters and the current and projected fiscal constraints on local governments, local efforts to preemptively improve chronic stressors such as housing and homelessness remain a challenge for cities facing direct impacts as well as those that might receive new residents. Lower-income residents in both the type 1 and type 2 cities are more subject to displacement and climate gentrification and sometimes these groups can clash with receiving community residents, depending on existing socio-economic and demographic makeup of recipient cities.

\section{Type 3: Climate Destinations}

Though no peer-reviewed materials have yet been published on this concept, there is growing discussion among scholars, think tanks, news outlets, and local elected officials pointing to a third type of city in the US climate migration landscape: the climate destination. The term "climate haven" first made headlines in a New York Times article that featured Professor Jesse Keenan, entitled "Want to Escape Global Warming? These Cities Promise Cool Relief." Since then, a significant amount of media attention has been given to the potential of legacy cities like Duluth, MN; Buffalo, NY; and Cincinnati, $\mathrm{OH}$, to absorb climate migrants from less hospitable places of the country in the coming decades (Sacks $\&$ Acevedo, 2020). These cities, and other climate destinations, have the following characteristics in common: (1) More manageable climate impacts, namely, are not prone to sea level rise or wildfires and prolonged heat waves; (2) ready access to fresh water supply; (3) high vacancy rates or abundance of affordable housing; (4) post-industrial, legacy cities with high infrastructural capacity (originally designed to support several thousand more residents than currently live there) (Pierre-Louis, 2019; Dagenais, 2019; Rossi 2019); (5) an expressed desire to grow and be welcoming; and (6) history of or interest in improving adaptive capacity through sustainability or resilience efforts. Despite the increase of curiosity on this subject, the climate destination has not been empirically defined in the literature, nor have many cities taken serious action to attract and receive new, climate-impacted residents. A few exceptions exist, as places that have managed an influx of climate migrants without experiencing the overwhelm of cities like Chico and Orlando, or those which are beginning to brand themselves as future climate destinations.

\section{Duluth, Minnesota}

At the 2019 Climate Futures conference at the University of Minnesota in Duluth, keynote speaker Jesse Keenan introduced the idea that the city of Duluth could serve as a "climate haven" for residents relocating from climateimpacted regions (Keenan, 2019). After thousands of hours of research to determine which US cities would have both the appropriate climate and the space to accommodate a large number of new residents, Keenan presented an economic development and marketing framework for the city that included the slogan: "Duluth: 99\% climate-proof" (Malo, 2019). While this concept felt rather absurd to many local residents (Hemphill, 2020), Mayor Emily Larson took note. But despite the apparent space, infrastructure, and ideal climate, Duluth faces its own challenges. "We struggle like many communities to ensure we have economic opportunity and safety and housing," Mayor Larson said (Reuters, 2019). Nevertheless, the community is actively engaged in participatory, equitable climate action and has set ambitions emission reduction goals; and with state and FEMA assistance, the city plans to spend $\$ 60$ million on coastal resilience and revitalization on a shoreline previously slammed by five storms. It already invested $\$ 140$ million in upgrading its wastewater management infrastructure, avoiding the combined sewer overflow of other Great Lakes cities (Hemphill, 2020).

\section{Buffalo, New York}

In 2019, during his State of the City speech, Mayor Byron Brown of the city of Buffalo proclaimed, "we have a tremendous opportunity as our planet changes. Based on scientific research, we know that Buffalo will be a climate refuge city for centuries to come." Buffalo had already received approximately 10,000 new resident climate migrants from Puerto Rico following Hurricane Maria in 2017 (Pierre, 2019), including nearly 500 school-age children (Spector, 2018). With an established Puerto Rican community, job opportunities for bilingual teachers, and a wide range of affordable housing options, Buffalo became an attractive option for many Puerto Rican's fleeing the hurricane's devastating impacts. "While thousands of people came seeking shortterm refuge, many remained when they found jobs, low housing prices, bilingual schools and a vibrant Latino community" (Dewey, 2018). As in the case of Orlando, CBOs such as Buffalo's Designing to Live Sustainably can help provide services to migrants and resources for cities for their climate adaptation efforts (Designing to Live Sustainably, 2020; Pierre-Louis, 2019). For a city whose population grew by just 2000 residents between 2010 and 2017, the new arrivals were a blessing. At the time, the city had an estimated 16,000 lots of underutilized or occupied urban space (McDonnell \& Shendruk, 2020). But these stocks will not last forever. According to Zillow, real estate in Buffalo is still far cheaper than the nationwide average, but both rents and home prices have been steadily rising since 2014 . 
If Buffalo wants to remain an affordable city for existing residents, avoid climate gentrification, and promote itself as a climate destination for newcomers, it must invest in policies and programs to increase its affordable housing stock and protect existing structures.

\section{Cincinnati, $\mathrm{OH}$}

In May 2018, the city of Cincinnati adopted its Green Plan, which acknowledged that due to its relative safety from hurricanes and wildfires, access to fresh water, and commitment to resilience, the city was "well situated to become a climate haven." After a significant population decline starting in the 1950 s, the city has struggled to regain its footing. The idea to become a climate destination emerged after the sustainability team realized that Ohio had received a sizable number of Hurricane Katrina evacuees in 2005 (Malo, 2019). The plan provides a rough guide for how the city can play host to 100 climate migrant households per year. The plan is intended to be equitable and cross-cutting, with goals ranging from vehicle electrification and other low-carbon transportation investments to urban agriculture and health. The city recognizes the importance of creating and preserving affordable housing, jobs, and social services if it is indeed to serve as a climate haven (Green Cincinnati Plan, 2018). With a current population of around 300,000 residents and an estimated 48,000 vacant housing units, the city has plenty of space. Larry Falkin, the city's former Office of Environment and Sustainability director, estimated that the city could absorb another 200,000 residents (Kiger, 2019).

Cincinnati and Buffalo are also legacy cities, a term coined in 2011 to describe "American cities that have rich histories and assets, and yet have struggled to stay relevant in an ever-changing global economy" (The 110th American Assembly, 2011). Once the economic engines of America, these communities experienced significant shrinkage through substantial population and job losses over multiple decades and struggled to diversify their economies and generate new jobs, particularly in communities of color (Brube \& Murray, 2018; Griffin et al., 2015). In the past, these communities served as destinations for immigrants escaping poverty and war and Black Southerners escaping racial servitude and violence (Berube, 2019). Today, legacy cities are still diverse, but suffer from the vestiges of redlining, segregation, and other exclusionary policies, with high levels of income inequality and poor health outcomes. Berube, (2019) argues, "this makes these communities particularly important focal points for efforts to close enduring racial economic divides in America." While the climate destination concept is relatively new, other legacy cities such as Flint, MI and Wilmington, DE have pursued greening and sustainability efforts as ways to remediate contaminated land, improve quality of life, address inequities, and create attractive new amenities (Bieretz, 2020). Resilience-building and climate adaptation among legacy cities also has precedent despite formidable challenges (Green Cincinnati Plan, 2018; Hughes, 2020; Sampson, 2014), and these communities now face momentum as critical "focal points" to help close social and economic divides (Berube \& Murray, 2018). Many legacy cities have long played host to refugees and immigrant communities and have created models and pathways for equitable, sustainable relocation (Balta Özgen, 2020). In Buffalo, there have been outsized economic benefits to hosting newcomers, including $\$ 622$ million in taxes paid, and $\$ 1.5$ billion in spending power in 2017 (New American Economy, n.d.).

What if cities have most of the type 3 characteristics, but lack the affordable housing or the interest in increasing their housing stock? For Ann Arbor, Michigan, a city of about 122,000 , this question is clear. Hauer's models (2017) predict Michigan could see more than 50,000 climate migrants by 2050, but Ann Arbor has neither the quantity of housing nor the political will to accept a large influx of newcomers. It does, however, have the appropriate climate, access to water, and is actively pursuing urban resilience and sustainability efforts (McDonnel \& Shendruk, 2020). A 2020 article in Business Insider asked 12 climate scientists to pick where they would like to live in the USA: their responses included Tulsa, Hartford, Boulder, San Diego, Sacramento, Minneapolis and Saint Paul, Charlotte; Pittsburgh; and Portland (Bendix, 2020), although the deadly and costly fire season of 2020 may make future migrants wary of air quality and smoke exposure in places like San Diego, Sacramento, and Portland, and many of these cities have their own climate risks and social stressors. In Pittsburgh, the city's chief resilience officer said, "I would be reluctant to call [climate migration] an opportunity because you're dealing with extremely negative challenges that are uprooting people's livelihoods." In addition, Pittsburgh faces issues with water pollution and limited mass transit (Rihl, 2019)—stressors that can quickly worsen during sudden-onset events as seen in Chico and Orlando. Cities with favorable climate conditions in our current environmental crisis could take advantage of the opportunity to brand themselves as a "climigrant friendly city" (Dagenais, 2019) but other ingredients including an affordable housing stock, transit and resiliency plans, and investments in critical infrastructure such as sewage and drinking water are critical.

\section{Key takeaways}

As slow and sudden-onset disasters are projected to worsen over the coming years, cities across the USA will continue to be impacted by climate migration, with waves of residents relocating out of harm's way or fleeing their homes 
and resettling in a new city. As highlighted through the case studies above, this population movement presents significant challenges for type 1 and type 2 cities and will disproportionately burden lower income residents within those communities if municipalities are unable to prepare. For type 3 cities, climate migrants may present growth opportunities, but strategies for embracing newcomers must take adequate measures to protect existing residents and create equitable, well-integrated communities. Indeed, in all city types, without protections in place to prevent evictions and climate gentrification, low-income residents and communities of color will bear the highest burden (Bonjour, 2020). Low-income households are more likely to move into damaged areas in response to lower housing prices; middle-income households move out of harm's way, and high-income households appear to remain situated due to their sufficient resources for insurance or self-protection (Smith et al., 2006). Lower income individuals and communities often face longer recovery times than wealthier communities (Pais \& Elliot 2008). Homeownership, socioeconomic status, and social networks are some of the other underlying conditions which determine migration after sudden-onset disasters (McLeman $\&$ Hunter, 2010) and the ability to return and rebuild. Relocation of wealthy residents can increase property values and local tax revenue, causing gentrification; or the departure of wealthy residents can depress local revenue. Because of the numerous outcomes of unmanaged scenarios, it is critical that local governments have the tools to ensure that those who needed to relocate have access to jobs, housing, and transportation options outside of high-risk areas (Table 1).

\section{Recommendations}

\section{Scenario planning}

In highlighting the various threats and opportunities for cities across the USA, we reiterate the conceptual utility of climate migration typologies for use in scenario planning, public engagement and participatory planning, and vulnerability assessments, as well as climate adaptation plans and comprehensive plans. Not every city will neatly fit into a category, nor are cities relegated to a permanent state. In fact, cities may experience each of the categories simultaneously or at different times. Utilizing this typology can help city, state, and federal officials examine response protocols, funding mechanisms, and cross-sector as well as interscalar coordination. The typology is intended to inspire broader conversations around holistic climate adaptation and preparedness efforts which must place equity and justice at the forefront. Through charrettes and other planning tools, cities, states, and federal agencies can optimize present and future opportunities, drive productive conversations among staff, elected officials, local communities, community-based organizations (CBOs), the private sector, and other stakeholders.

\section{Increased coordination}

Climate migration experts can and should leverage existing inter-city networks-both climate-related and general- to draw awareness to this urgent challenge to increase capacity among local elected officials and city staff. Similarly, municipal staff, CBOs, philanthropic networks, and national nonprofits across the country may lack the expertise and awareness around climate migration issues to adequately support local residents, but state, federal, and philanthropic funds can support capacity-building efforts and increased coordination. State and federal leadership on climate migration is also essential - and lacking. Just 33 states in the USA have adopted or begun the process of preparing a Climate Action Plan (C2ES, 2020). Existing federal programs such as Building Resilient Infrastructures and Communities (BRIC) and the Stafford Act could be amended or "unlocked" to support type 2 and 3 cities that seek to preemptively prepare for future climate migrants or support recipient cities faced with incoming migrants. Federal coordination and funding could incentivize additional legacy cities to support climate migrants through improvements infrastructure, public services, and housing protections for existing residents. It could create pathways to help redirect residents evacuating disasters to cities set up to host them or support agreements between states that foster relationships between type 1 and type 3 cities. Acknowledging indirect impacts on type 2 cities for example can help remove barriers to much needed emergency management and resettlement support. Improved pre-disaster coordination among cities, aid organizations, $\mathrm{CBOs}$, and state and federal agencies could also lessen this burden on local governments. Regional collaboration across cities and counties and pre-disaster agreements to share resources for displaced residents, as well as stronger policies to protect existing affordable housing stocks in high-risk regions, could be enacted.

\section{Conclusions and future research}

Despite a relative increase in coverage of climate migration in the domestic media, climate migration remains a niche issue in the public policy circles of small- and mid-sized cities. Federal guidance is always a cornerstone of public programs, and although the Biden administration has prioritized climate change mitigation, little action has been specifically directed towards climate change adaptation. Due to this lag, robust and coordinated approaches to addressing climate migration specifically will take time to design and implement. In the meantime, it may be worth reexamining 


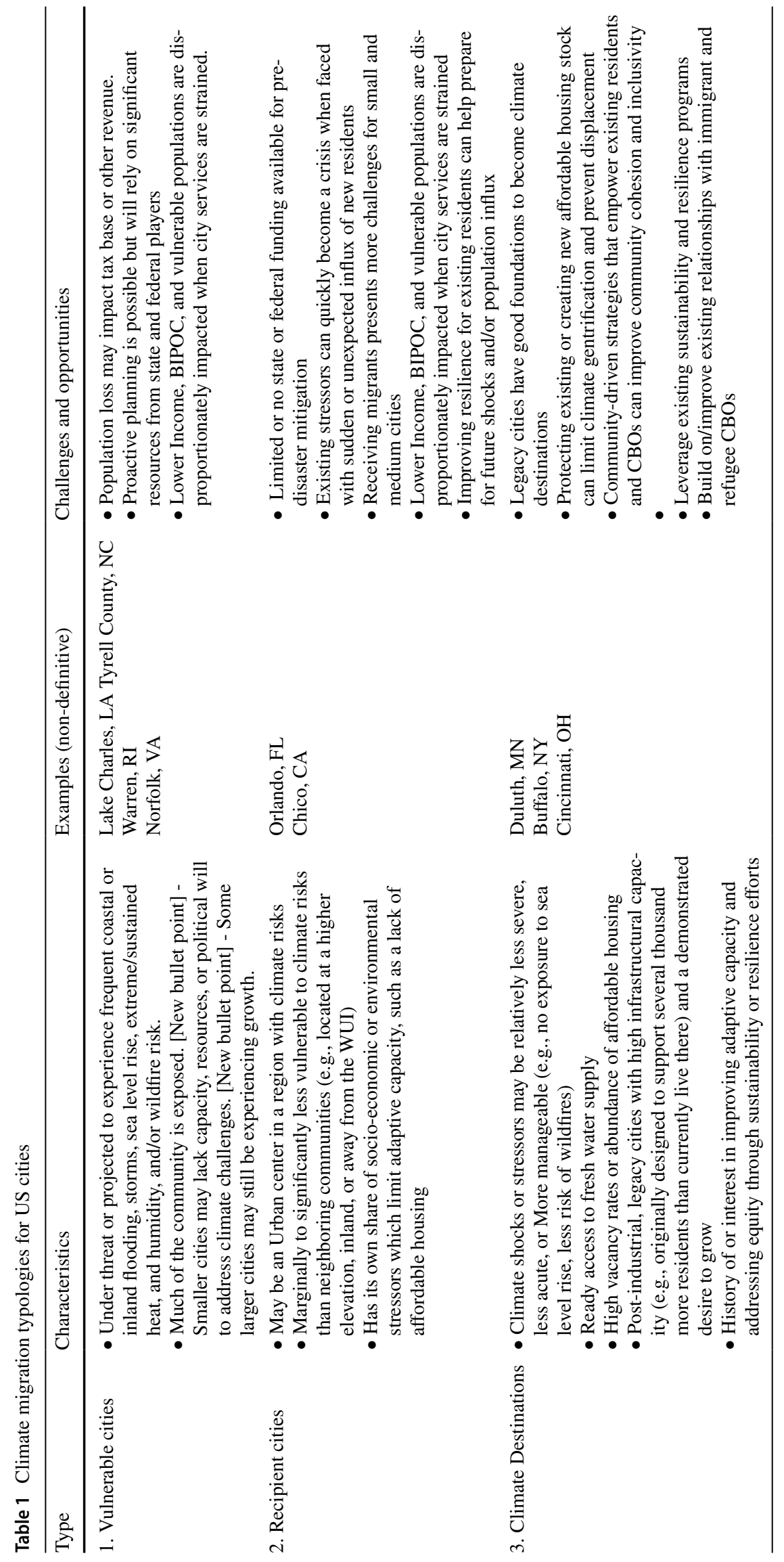


existing programs that fund affordable housing, economic development, and infrastructural investment with an eye to the three critical trends outlined in this paper.

Additional research is needed to test the functional utility of a typological framework on informing local action on climate migration. In the meantime, it is critical to test theoretical assumptions of climate migration impacts by soliciting input from local governments on pathways for policy implementation, especially since local decision makers are the key to ensuring more equitable outcomes for vulnerable residents. Guided by this imperative, we are continuing this field of study through outreach to local officials faced with climate migration concerns. The outcome of these pursuits may lead to workshops and trainings that support and leverage the knowledge of local officials while including local communities in the discussion. In doing so, this work aims to help build a more informed and robust set of strategies as policymakers work to design equitable responses to climate migration in US cities.

The longer we wait, the harder it will be to protect frontline communities and the more costly relocation and receiving plans will be. Working with cities and local communities, we can reframe climate-induced migration and internal displacement not just as threats but also as critical opportunities to revitalize recipient and destination cities, while providing those communities that have little option but to retreat with the chance to resettle with dignity in a new, welcoming city of their choosing. Cities that are already investing in holistic resiliency efforts on climate preparedness, affordable housing, and green job creation-particularly in lower income and communities of color-may find they are better positioned to receive future residents. These cities will have long established the critical muscle memory and relationships needed to collaborate across city departments and with neighboring jurisdictions to address the complex, multi-faceted challenges of the decades to come.

\section{References}

Ajibade, I., Sullivan, M., \& Haeffner, M. (2020). Why climate migration is not managed retreat: six justifications. Global Environmental Change, 65, 102187

Albouy D, Graf W, Kellogg R, Wolff H (2016) Climate amenities, climate change, and American quality of life. Journal of the Association of Environmental and Resource Economists 3(1):205-246. https://doi.org/10.1086/684573

Alvarez, L. (2017). A great migration from Puerto rico is set to transform Orlando. The New York Times. https://www.nytimes.com/ 2017/11/17/us/puerto-ricans-orlando.html

America's Great Migrations. (n.d.). University of Washington. Retrieved September 15, 2020, from https://depts.washington. edu/moving $1 /$

Arenstam Gibbons SJ, Nicholls RJ (2006) Island abandonment and sea-level rise: an historical analog from the Chesapeake Bay,
USA. Global Environmental Change 16(1):40-47. https://doi. org/10.1016/j.gloenvcha.2005.10.002

Aune, K. T., Gesch, D., \& Smith, G. S. (2020). A spatial analysis of climate gentrification in Orleans Parish, Louisiana post-Hurricane Katrina. Environmental Research, 185, 109384. https:// doi.org/10.1016/j.envres.2020.109384

Balta Özgen, A. (2020). Buffalo, NY: good practice in refugee resettlement. Global Dialogue - Magazine of the International Sociological Association, 10(1). Retrieved September 15, 2020, from https://globaldialogue.isa-sociology.org/buffalo-ny-goodpractice-in-refugee-resettlement/

Beckwith, J. (2019). Modeling climate driven urban migration in the United States. REU Final Reports. https://pdxscholar.library. pdx.edu/reu_reports/14

Bendix, A. (2020, February 27). Where to live to avoid natural disasters, according to climatologists. Business Insider. https:// www.businessinsider.com/where-to-live-to-avoid-natural-disas ter-climatologists-2018-8\#unfortunately-hawaii-is-expectedto-see-more-frequent-and-intense-tropical-storms-so-scien tists-dont-recommend-living-there-10

Berube, Alan. (2019). SMALL and MIDSIZED LEGACY COMMUNITIES. Metropolitan Policy Program - Brookings. https:// www.brookings.edu/wp-content/uploads/2019/11/201911_ BrookingsMetro_Legacy-communities_Berube_Final.pdf

Berube, Allan, \& Murray, C. (2018, April 19). Renewing America's economic promise through older industrial cities. Brookings. https://www.brookings.edu/research/older-industrial-cities/

Betsill MM, Bulkeley H (2006) Cities and the multilevel governance of global climate change. Global Governance: A Review of Multilateralism and International Organizations 12(2):141160. https://doi.org/10.1163/19426720-01202004

Bieretz, B. (2020, April 1). Small to midsize legacy cities pursue green and sustainable innovations. Housing Matters - Urban Institute. https://housingmatters.urban.org/articles/small-midsi ze-legacy-cities-pursue-green-and-sustainable-innovations

Binder, S. B., \& Greer, A. (2016). The devil is in the details: linking home buyout policy, practice, and experience after Hurricane Sandy. Politics and Governance, 4(4), 97-106. https://doi.org/ 10.17645/pag.v4i4.738

Bonjour, R (2020). Flooding the cities: how land use policies contribute to climate gentrification. Seton Hall Legislative Journal 44(1):91-114

Brady, A.F. (2015). Buyouts and Beyonds: Politics, Planning, and the Future of Staten Island's East Shore after Superstorm Sandy. Doctoral dissertation. Massachusetts Institute of Technology

Bronen, R. (2013). Climate-induced displacement of Alaska native communities. Alaskan Immigration Justice Project \& Brookings-LSE Project on Internal Displacement. https://www.brook ings.edu/wp-content/uploads/2016/06/30-climate-alaskabronen-paper.pdf

Brunkard J, Namulanda G, Ratard R (2008) Hurricane Katrina deaths, Louisiana, 2005. Disaster Medicine and Public Health Preparedness 2(4):215-223. https://doi.org/10.1097/DMP. 0b013e31818aaf55

Butte Countywide Homeless Continuum of Care. (2017). Butte County Homelessness Report. Retrieved September 12, 2020. http://www.buttehomelesscoc.com/uploads/1/1/7/5/11750 0423/2017_butte_pit_summary_community_report_-_final.pdf

O’Neill, Stephanie (2019, April 24). Camp Fire Victims Struggle With Psychological Scars that Scorched The Community. https://www.npr.org/2019/04/24/716873131/camp-fire-victi ms-struggle-with-psychological-scars-that-scorched-thecommunity

C2ES. (2020, September). U.S. State Climate Action Plans. https:// www.c2es.org/document/climate-action-plans/ 
City of Norfolk. (2016). Norfolk Vision 2100. City of Norfolk. https:// www.norfolk.gov/DocumentCenter/View/27768/Vision-2100--FINAL?bidId $\equiv$

Clark, W. A. V., \& Maas, R. (2013). Interpreting Migration Through the Prism of Reasons for Moves. Population, Space and Place, 21(1), 54-67. https://doi.org/10.1002/psp.1844

Climate Central, \& Zillow. (2019). Ocean at the Door: New Homes and the Rising Sea. https://www.climatecentral.org/news/ocean-atthe-door-new-homes-in-harms-way-zillow-analysis-21953

Collins, T. W., Grineski, S. E., \& Chakraborty, J. (2018). Environmental injustice and flood risk: A conceptual model and case comparison of metropolitan Miami and Houston, USA. Regional Environmental Change, 18(2):311-323. https://doi.org/10.1007/ s10113-017-1121-9

Counties in South and West Lead Nation in Population Growth. (2019). The United States Census Bureau. https://www.census.gov/newsr oom/press-releases/2019/estimates-county-metro.html

Cragg M, Kahn M (1997) New estimates of climate demand: evidence from location choice. Journal of Urban Economics 42(2):261284. https://doi.org/10.1006/juec.1996.2027

Dagenais, T. (2019, April 16). Climate change, "climigration," and the Rust Belt: The New York Times joins Jesse Keenan for a look at the future of Duluth. Harvard Graduate School of Design. https:// www.gsd.harvard.edu/2019/04/extreme-weather-climate-migra nts-and-the-rust-belt-the-new-york-times-joins-jesse-keenan-fora-look-at-the-future-of-duluth/

Dahl, K., Cleetus, R., Spanger-Siegfried, E., Udvardy, S., Caldas, A., \& Worth, P. (2018). Underwater: rising seas, chronic floods, and the implications for US Coastal Real Estate. Union of Concerned Scientists. https://www.ucsusa.org/sites/default/files/attach/2018/ 06/underwater-analysis-full-report.pdf

Davenport, C., \& Robertson, C. (2016, May 2). Resettling the first American 'climate refugees'. The New York Times. https://www. nytimes.com/2016/05/03/us/resettling-the-first-american-clima te-refugees.html

Deaton, J. (2019, December 9). Will Buffalo, New York, become a climate change haven? Grist. https://grist.org/climate-energy/ will-buffalo-new-york-become-a-climate-change-haven/

DeGood, K. (2020, May 6). Climate Change and Municipal Finance. Center for American Progress. https://www.americanprogress. org/issues/economy/reports/2020/05/06/484173/climate-changemunicipal-finance/

Deryugina, T., Kawano, L., \& Levitt, S. (2018). The Economic Impact of Hurricane Katrina on Its Victims: Evidence from Individual Tax Returns. American Economic Journal: Applied Economics, 10(2):202-233. https://doi.org/10.1257/app.20160307

Designing to Live Sustainably. (n.d.). D21s.Org. Retrieved September 15, 2020, from https://d21s.org/

Dewey, C. (2018). Hurricane refugees liked what they found in Buffalo - so they're staying. The Buffalo News. https://buffalonews.com/ news/local/hurricane-refugees-liked-what-they-found-in-buffaloso-theyre-staying/article_c69708c3-fc0a-583f-a8ce-c8f2060c51 4d.html

Dietrich, T. (2020). Virginia city seeks conservation solution for floodprone properties. Bay Journal. https://www.bayjournal.com/ news/climate_change/virginia-city-seeks-conservation-solut ion-for-flood-prone-properties/article_bc5a701a-ec62-11ea8c53-ebba58aa49dd.html

Echenique, M. (2018, May 11). Where Puerto Rico's Residents Migrated Since Maria. Bloomberg. https://www.bloomberg.com/ news/articles/2018-05-11/where-puerto-rico-s-residents-migra ted-since-maria

Fan, Q., Klaiber, H. A., \& Fisher-Vanden, K. (2016). Does Extreme Weather Drive Interregional Brain Drain in the U.S.? Evidence from a Sorting Model. Land Economics, 92(2):363-388. https:// doi.org/10.3368/le.92.2.363
Ferris, E. (2014, June 9). Disasters and Displacement: What We Know, What We Don't Know. ReliefWeb. https:// reliefweb.int/report/world/disasters-and-displaceme nt-what-we-know-what-we-don-t-know

Findlay AM (2011) Migrant destinations in an era of environmental change. Global Environmental Change 21:S50-S58. https:// doi.org/10.1016/j.gloenvcha.2011.09.004

Florida, R. (2019). How natural disasters can spur gentrification. Bloomberg.Com. https://www.bloomberg.com/news/articles/ 2019-02-12/new-orleans-gentrification-tied-to-hurricane-katri na

Freudenberg R, Calvin E, Tolkoff L, Brawley D (2016) Buy-in for buyouts: the case for managed retreat from flood zones. Lincoln Institute of Land Policy

Fulton W, Hazle SG, Choudary W, Sherman S (2020) The urban sun belt: an overview. Rice University Kinder Institute for Urban Research. https://doi.org/10.25611/08BZ-KJ50

Government Accountability Office. (2020). A Climate Migration Pilot Program Could Enhance the Nation's Resilience and Reduce Federal Fiscal Exposure. (GAO Publication No. 20-488). Washington, D.C.: U.S. Government Printing Office.

Gramling, C. (2020). What data do cities like Orlando need to prepare for climate migrants? Science News. https://www.sciencenews. org/article/climate-change-migrants-destination-cities-data-orlan do

Green Cincinnati Plan. (2018). City of Cincinnati. https://www. cincinnati-oh.gov/oes/climate/climate-protection-green-cinci nnati-plan/

Griffin, T., Yang, E., Flournoy, M., \& Bartocci, J. (2015). Mapping American Legacy Cities. J. Max BOND Center on Design for the Just City. https://ssa.ccny.cuny.edu/wp-content/uploads/2015/12/ MappingAmericanLegacyCities_15Dec2015.pdf

Gutmann MP, \& Field V (2010) Katrina in historical context: environment and migration in the U.S. Population and Environment 31(1-3):3-19. https://doi.org/10.1007/s11111-009-0088-y

Martín, C. (2019). Who are America's "climate migrants," and where will they go? Urban Institute. https://www.urban.org/urban-wire/ who-are-americas-climate-migrants-and-where-will-they-go

Hagerty, C. (2019). The survivors. https://www.vox.com/the-highl ight/2019/10/16/20908291/camp-fire-wildfire-california-parad ise-survivors

Hauer, M. (2017). Migration induced by sea-level rise could reshape the US population landscape. Nat Clim Change, 7(5). https://doi. org/10.1038/nclimate3271

Hauer ME, Evans JM, Mishra DR (2016) Millions projected to be at risk from sea-level rise in the continental United States. Nature Climate Change 6(7):691-695. https://doi.org/10.1038/nclim ate 2961

Hauer ME, Fussell E, Mueller V, Burkett M, Call M, Abel K, McLeman R, Wrathall D (2020) Sea-level rise and human migration. Nature Reviews Earth \& Environment 1(1):28-39. https://doi. org/10.1038/s43017-019-0002-9

Havlak, J. (2020, June 3). North Carolina's local governments face a grim financial future. Montgomery Herald. http://www.montg omeryherald.com/news/article_dbfca034-a5d4-11ea-a333-6b9c7 95cdebf.html

Hayes, A. C. (2016). Population dynamics and climate change: a challenging frontier for the intrepid demographer. Vienna Yearbook of Population Research, 33-36. https://doi.org/10.1553/popul ationyearbook $2015 \mathrm{~s} 033$

Hemphill, S. (2020). Climate change comes to Duluth-one of America's "climate refuge cities" [Ensia]. Agate Magazine. https:// ensia.com/articles/duluth-climate-change-economy/

Hermann, V. (2017). The United States' Climate Change Relocation Plan. The Atlantic Council. https://issuu.com/atlanticcouncil/ docs/the_united_states_climate_change_re 
Hino M, Field CB, Mach KJ (2017) Managed retreat as a response to natural hazard risk. Nature Climate Change 7(5):364-370. https://doi.org/10.1038/nclimate3252

Hinojosa, J., Román, N., \& Meléndez, E. (2018). Puerto Rican PostMaria Relocation by States (p. 16). Center for Puerto Rican Studies, CUNY.

Hori M, Schafer MJ, Bowman DJ (2009) Displacement dynamics in Southern Louisiana after Hurricanes Katrina and Rita. Population Research and Policy Review 28(1):45-65. https://doi.org/ 10.1007/s11113-008-9118-1

Hughes S (2020) Principles, drivers, and policy tools for just climate change adaptation in legacy cities. Environmental Science \& Policy 111:35-41. https://doi.org/10.1016/j.envsci.2020.05.007

Increased Flooding Plagues Tyrrell County I Coastal Review Online. (2019). https://www.coastalreview.org/2019/05/increased-flood ing-plagues-tyrrell-county/

Jones B, O’Neill BC, McDaniel L, McGinnis S, Mearns LO, Tebaldi C (2015) Future population exposure to US heat extremes. Nature Climate Change 5(7):652-655. https://doi.org/10.1038/nclim ate 2631

Keenan, J. (2019). Destination Duluth: the fact and fiction of a shared climate future. University of Minnesota Duluth. https://www. youtube.com/watch? $\mathrm{v}=\mathrm{v}$ UhSckQsrwY \& feature $=$ youtu.be

Keenan JM, Hauer ME (2020) Resilience for whom? Demographic change and the redevelopment of the built environment in Puerto Rico. Environmental Research Letters 15(7):074028. https://doi. org/10.1088/1748-9326/ab92c2

Keenan, J. M., Hill, T., \& Gumber, A. (2018). Climate gentrification: From theory to empiricism in Miami-Dade County, Florida. Environmental Research Letters, 13(5):054001. https://doi.org/ 10.1088/1748-9326/aabb32

Kiger, P. (2019). Could some cities benefit from migration driven by climate change?. Urban Land Magazine. https://urbanland.uli. org/economy-markets-trends/could-some-cities-benefit-frommigration-driven-by-climate-change/

Klein, N. (2019). Forged in fire: California's Lessons for a Green New Deal. The Intercept. https://theintercept.com/2019/11/07/calif ornia-wildfires-green-new-deal/

de Koning K, Filatova T (2020) Repetitive floods intensify outmigration and climate gentrification in coastal cities. Environmental Research Letters 15(3):034008. https://doi.org/10.1088/17489326/ab6668

Koslov L (2016) The case for retreat. Public Culture 282(79):359-387. https://doi.org/10.1215/08992363-3427487

Kozak, C. (2020, June 18). Sea Level Rise Puts Septic, Sewers At Risk. CoastalReview.Org. https://coastalreview.org/2020/06/ sea-level-rise-puts-septic-sewers-at-risk/

Lavey, N. (2014). After Hurricane Sandy, a community decides whether to leave I The New Yorker. New Yorker. https://www.newyorker. com/news/news-desk/hurricane-sandy-retreat-waters-edge

Lustgarten, A. (2020). The great climate migration has begun. The New York Times. https://www.nytimes.com/interactive/2020/07/23/ magazine/climate-migration.html

Malo, S. (2019). Future cool: Minnesota city ponders new boom as a climate migrant destination I Reuters. Reuters. https://www. reuters.com/article/us-cities-future-usa/future-cool-minnesotacity-ponders-new-boom-as-a-climate-migrant-destination-idUSK BN1WV1DS

Mann ML, Berck P, Moritz MA, Batllori E, Baldwin JG, Gately CK, Cameron DR (2014) Modeling residential development in California from 2000 to 2050: Integrating wildfire risk, wildland and agricultural encroachment. Land Use Policy 41:438-452. https:// doi.org/10.1016/j.landusepol.2014.06.020

McDonnell, T., \& Shendruk, A. (2020). It's time to prepare cities for people uprooted by climate change. Quartz. https://qz.com/18952 63/how-cities-can-prepare-to-support-climate-migrants/
McFarland, C. K., \& Pagano, M. A. (2020). City Fiscal Conditions Report. National League of Cities. https://www.nlc.org/sites/ default/files/users/user57221/City_Fiscal_Conditions_2020_ FINAL.pdf

Mckay, R. R. (1982). Texas Mexican repatriation during the Great Depression. [Thesis]. https://shareok.org/handle/11244/4956

McLeman, R. A., \& Hunter, L. M. (2010). Migration in the context of vulnerability and adaptation to climate change: Insights from analogues. Wiley Interdisciplinary Reviews. Climate Change, 1(3):450-461. https://doi.org/10.1002/wcc.51

Meyers, T. (2019, November 7). After the Camp Fire, paradise residents got sicker. So Local Nurses Founded a Clinic. Direct Relief. https://www.directrelief.org/2019/11/after-the-camp-fireparadise-residents-got-sicker-so-local-nurses-founded-a-clinic/

Neumann, B., Vafeidis, A. T., Zimmermann, J., \& Nicholls, R. J. (2015). Future coastal population growth and exposure to sealevel rise and coastal flooding - a global assessment. PLOS ONE, 10(3), e0118571. https://doi.org/10.1371/journal.pone.0118571

New American Economy. (n.d.). Retrieved September 15, 2020, from https://www.newamericaneconomy.org/map-the-impact/

Nijhuis, M. (2017). When is it time to retreat from climate change? The New Yorker. https://www.newyorker.com/tech/annals-of-techn ology/when-is-it-time-to-retreat-from-climate-change

NOAA. (2020). Billion-Dollar Weather and Climate Disasters. (2020). NOAA National Centers for Environmental Information (NCEI). https://www.ncdc.noaa.gov/billions/

Padro Ocasio, B. (2019, February 2). Puerto Ricans struggled more in Central Florida [News]. The Ledger. https://www.theledger.com/ news/20190202/puerto-ricans-struggled-more-in-central-florida

Pais, J., \& Elliot, J. (2008). Places as Recovery Machines: Vulnerability and Neighborhood Change After Major Hurricanes. Social Forces, 86(4):1415-1453. https://doi.org/10.1353/SOF.0.0047

Palinkas LA (2020) The California Wildfires. In: Palinkas LA (ed) Global climate change, population displacement, and public health: the next wave of migration. Springer International Publishing, pp 53-67. https://doi.org/10.1007/978-3-030-41890-8_4

Peri, G., Rury, D., \& Wiltshire, J. (2020). The economic impact of migrants from Hurricane Maria (No. w27718; p. w27718). National Bureau of Economic Research. https://doi.org/10.3386/ w27718

Pierre-Louis, K. (2019). Want to escape global warming? These cities promise cool relief. The New York Times. https://www.nytimes. com/2019/04/15/climate/climate-migration-duluth.html

Plastrik, P., \& Cleveland, J. (2019). Can it happen here? Improving the prospect for managed retreat by US cities. 47. Innovation Network for Communities.

Radeloff VC, Helmers DP, Kramer HA, Mockrin MH, Alexandre PM, Bar-Massada A, Butsic V, Hawbaker TJ, Martinuzzi S, Syphard AD, Stewart SI (2018) Rapid growth of the US wildland-urban interface raises wildfire risk. Proceedings of the National Academy of Sciences 115(13):3314-3319. https://doi.org/10.1073/ pnas. 1718850115

Rainey, J. (2019). Fire turns Chico, California, into a boomtown, but at what cost? https://www.nbcnews.com/news/us-news/fire-turnschico-california-boomtown-what-cost-n960081

Ratcliffe, C., Congdon, W. J., Stanczyk, A., Teles, D., Martín, C., \& Kotapati, B. (2019). Insult to injury: natural disasters and residents' financial health. Urban Institute. https://www.urban.org/ research/publication/insult-injury-natural-disasters-and-resid ents-financial-health

Rigaud, K. K.; de Sherbinin, A,; Jones, B.; Bergmann, J.; Clement, V.; Ober, K.; Schewe, J.; Adamo, S.; McCusker, B.; Heuser, S.; Midgley, A. (2018). Groundswell : Preparing for Internal Climate Migration. World Bank, Washington, DC. @ World Bank. https:// openknowledge.worldbank.org/handle/10986/29461 License: CC BY 3.0 IGO 
Rihl, J. (2019). Climate migration: could Pittsburgh be a haven for residents leaving other regions? PublicSource I News for a Better Pittsburgh. https://www.publicsource.org/climate-migra tion-could-pittsburgh-be-a-haven-for-residents-leaving-otherregions/

Robinson C, Dilkina B, Moreno-Cruz J (2020) Modeling migration patterns in the USA under sea level rise. PLOS ONE 15(1):e0227436. https://doi.org/10.1371/journal.pone.0227436

Romero, S. (2018). In a Walmart Lot, a Rough Refuge for California Wildfire Evacuees. The New York Times. https://www.nytim es.com/2018/11/18/us/california-wildfire-walmart-tent.html

Rossi, M. (2019). Some northern cities could be reborn as 'climate havens' » Yale Climate Connections. Yale Climate Connections. https://yaleclimatemediaforum.org/2019/08/some-north ern-cities-could-be-reborn-as-climate-havens/

Ruiter, J. (2017). Thousands enroll in Florida schools in wake of Hurricane Maria; housing a major issue. Orlandosentinel. Com. https://www.orlandosentinel.com/news/lake/os-puertorico-hurricane-irma-student-enrollment-central-florida-20171 128-story.html

Sacks, E., \& Acevedo, N. (2020, January 14). Move to Buffalo? With Earth warming, northern cities could become oases. Retrieved August 2, 2020, from https://www.nbcnews.com/science/envir onment/buffalo-oasis-scientists-say-warmer-earth-could-makecolder-cities-n1113711

Sampson, N. (2014). Planning for climate change in legacy cities: the case of Detroit, Michigan. Michigan J Sustain, 2(20150506). https://doi.org/10.3998/mjs.12333712.0002.004

Sellers, F. S. (2019a). Driven from Paradise by fire, evacuees worry that gentrification will prevent them from coming home. Washington Post. https://www.washingtonpost.com/national/parad ise-reclaimed/2019/06/20/0822184a-82f1-11e9-933d-75010 70ee669_story.html

Sellers, F. S. (2019b). Forced from Paradise: life after one of America's deadliest wildfires-Washington Post. https://www.washi ngtonpost.com/graphics/2019/national/paradise-fire-displacedresidents/?itid=lk_inline_manual_24

Sesin, C. (2017, November 30). Over 200,000 Puerto Ricans have arrived in Florida since Hurricane Maria. NBC News. https:// www.nbcnews.com/news/latino/over-200-000-puerto-ricanshave-arrived-florida-hurricane-maria-n825111

Sherman, A. (2020). Warren's rising waters compel officials to plan retreat. EcoRI News. https://www.ecori.org/climate-change/ 2020/9/11/warrens-rising-waters-demand-managed-retreat

Shi L, Chu E, Anguelovski I, Aylett A, Debats J, Goh K, Schenk T, Seto KC, Dodman D, Roberts D, Roberts JT, VanDeveer SD (2016) Roadmap towards justice in urban climate adaptation research. Nature Climate Change 6(2):131-137. https://doi.org/ $10.1038 /$ nclimate 2841

Siders AR (2019) Social justice implications of US managed retreat buyout programs. Climatic Change 152(2):239-257. https:// doi.org/10.1007/s10584-018-2272-5

Siegler, K. (2019a). Paradise, Calif., Water is contaminated but residents are moving back anyway. NPR.Org. https://www.npr.org/ 2019/04/16/713430751/paradise-calif-water-is-contaminatedbut-residents-are-moving-back-anyway

Siegler, K. (2019b). More than 1,000 families still searching for homes 6 months after the Camp Fire. NPR.Org. https://www. npr.org/2019/05/08/721057281/more-than-1-000-families-stillsearching-for-homes-6-months-after-the-camp-fire

Sinha, P., \& Cropper, M. L. (2013). The value of climate amenities: evidence from US migration decisions (Working Paper No. 18756; Working Paper Series). National Bureau of Economic Research. https://doi.org/10.3386/w18756
Smith SK, McCarty C (1996) Demographic effects of natural disasters: a case study of hurricane andrew. Demography 33(2):265-275

Smith VK, Carbone JC, Pope JC, Hallstrom DG, Darden ME (2006) Adjusting to natural disasters. Journal of Risk and Uncertainty 33(1):37-54. https://doi.org/10.1007/s11166-006-0170-0

Snarr, P. (2019). Struggles in Chico show wider effects of wildfire I KRON4. KRON 4. https://www.kron4.com/news/struggles-inchico-show-wider-effects-of-wildfire/

Spector, J. (2018). Puerto Rico: NY adds 2,246 displaced students. Wgrz.Com. https://www.wgrz.com/article/news/local/newyork/puerto-rico-ny-adds-2246-displaced-students/71-52877 1618

Spidalieri K \& Bennett A (2020) Managed Retreat Toolkit. Georgetown Climate Center. https://www.georgetownclimate.org/ adaptation/toolkits/managed-retreat-toolkit/introduction.html

The 110th American Assembly. (2011, April 11-14). Reinventing America's Legacy Cities: Strategies for cities losing population. https://community-wealth.org/sites/clone.communitywealth.org/files/downloads/report-birch-et-al.pdf

US Census Bureau. (n.d.). CPS Historical Geographic Mobility/ Migration Graphs. The United States Census Bureau. Retrieved September 15, 2020, from https://www.census.gov/library/ visualizations/time-series/demo/historic.html

US Census Bureau. (2019, April 18). Counties in South and West Lead Nation in Population Growth. (2019, April 18). The United States Census Bureau. Retrieved September 15, 2020 from https://www.census.gov/newsroom/press-releases/2019/ estimates-county-metro.html

USGCRP. (2018). Fourth National Climate Assessment. https:// nca2018.globalchange.govhttps://nca2018.globalchange.gov/ chapter/8

van Holm EJ, Wyczalkowski CK (2019) Gentrification in the wake of a hurricane: New Orleans after Katrina. Urban Studies 56(13):2763-2778. https://doi.org/10.1177/0042098018 800445

Wade, M. (2019). City of Chico "overwhelmed" by influx of Camp Fire survivors. Abc10.Com. https://www.abc10.com/article/ news/city-of-chico-overwhelmed-by-influx-of-camp-fire-survi vors/103-3bb43c11-124a-4742-8278-3b8b6af08648

Warner K, Hamza M, Oliver-Smith A, Renaud F, Julca A (2010) Climate change, environmental degradation and migration. Natural Hazards 55(3):689-715. https://doi.org/10.1007/ s11069-009-9419-7

Washburn, D. (2018, December 12). New location found for California high school destroyed by wildfire. EdSource. https://edsou rce.org/2018/new-location-found-for-california-high-schooldestroyed-by-wildfire/605983

Wick, J. (2019). Newsletter: how the Camp Fire reshaped a town where nothing burned. Los Angeles Times. https://www.latim es.com/california/story/2019-11-08/camp-fire-chico-californianewsletter

Wiggins M (2018) Eroding paradigms: heritage in an age of climate gentrification. Change over Time 8(1):122-130. https://doi.org/ $10.1353 / \cot .2018 .0006$

Wilkerson I (2011) The warmth of other suns. Vintage Books

Wilson, S. (2019, August 3). Secondary burns: Chico, Calif., is in tumult after a fire emptied out neighboring Paradise. Washington Post. https://www.washingtonpost.com/national/secondaryburns-chico-calif-is-in-tumult-after-a-fire-emptied-out-neigh boring-paradise/2019/08/02/26263e38-b2e5-11e9-951e-de024 209545d_story.html

Wind TR, Joshi PC, Kleber R, Komproe IH (2013) The impact of recurrent disasters on mental health: a study on seasonal floods in Northern India. Prehospital and Disaster Medicine: the 
Official Journal of the National Association of EMS Physicians and the World Association for Emergency and Disaster Medicine in Association with the Acute Care Foundation 28(3):1-7. https://doi.org/10.1017/S1049023X13000290

Wulfhorst, E. (2019). Mental health at risk as California wildfire threat grows I Reuters. Reuters. https://www.reuters.com/artic le/us-usa-climate-mentalhealth/mental-health-at-risk-as-calif ornia-wildfire-threat-grows-idUSKBN1XU100

Zaninetti J-M, Colten CE (2012) Shrinking New Orleans: post-Katrina population adjustments. Urban Geography 33(5):675-699. https://doi.org/10.2747/0272-3638.33.5.675 